\title{
National Interest or \\ Transnational Alliances? Japanese Policy on the Comfort Women Issue
}

\author{
Yangmo Ku
}

\begin{abstract}
When and why does a perpetrator state take a contrite stance on its past wrongs? More specifically, why do Japanese behaviors differ over time in addressing apology and compensation with regard to the comfort women issue? In this article I address these questions by testing two hypotheses, utilizing an instrumentalist approach and a transnationalpolitical activism model. The former posits a perpetrator state is more likely to take a contrite stance on its past misdeeds when it calculates such action is in its security and/or economic interests. The latter hypothesizes that when transnational activism is powerful and a perpetrator state is led by a progressive ruling coalition, the state is more likely to adopt conciliatory policies toward historical issues. I find that the transnational-political activism model possesses more explanatory power than instrumentalism for within-case variations in Japanese behavior toward the comfort women issue. The two approaches are not, however, mutually exclusive and are complementary in some regards. The effect of transnational activism is heightened when the target state is faced with other geopolitical incentives and/or when the target state is led by a progressive ruling coalition and has weak conservative reaction. KEYWORDS: instrumentalism, transnational-political activism model, comfort women, apology and compensation, postwar Japanese history policy
\end{abstract}

DURING WORLD WAR II, JAPAN FORCIBLY DRAFTED VAST NUMBERS OF women from its colonized and occupied countries into military prostitution. These comfort women, ${ }^{1}$ whose numbers are estimated at 50,000 to 200,000 , were forced into sexual slavery for Japanese troops between 1932 and 1945 (Piper 2001). Comfort stations were first established in Shanghai around 1932, yet the outbreak of the Japanese-Chinese War in 1937 prompted the Japanese military to adopt the general policy of establishing military brothels in various occupied locations (Yoshimi 2000, 43-51). Despite the lack of accurate information, unearthed documents 
and testimony indicate 80 to 90 percent of comfort women were Koreans in their mid-teens and early twenties. The most commonly used method of recruitment was to deceive women with false promises of employment in Japan (Soh 2008, 107). Under harsh conditions, these comfort women suffered traumatic experiences during and after World War II.

In light of this historical background, the way Japan has addressed its past wrongs has varied significantly over time. Up until the late 1980s, the Japanese government denied any Japanese military involvement in organizing the comfort women system by attributing it to private enterprise. In the early and mid-1990s, the Japanese government issued somewhat apologetic statements regarding the comfort women issue, and also helped establish a nongovernmental fund, the Asian Women's Fund (AWF). However, the establishment of the AWF was not equivalent to full-fledged state compensation and apology (Soh 2003). The Japanese government did not move forward with these limited but positive changes with respect to apology and compensation in the late 1990s, and it has in fact regressed (Saaler 2005, 52-55). For example, high-ranking Japanese government officials made a series of provocative statements that either denied or whitewashed the wartime atrocities perpetrated by the Japanese against the comfort women. Additionally, Japanese Prime Minister Abe Shinzo denied Japan's coercive recruitment of comfort women in March 2007, although he reversed his stance on the issue a month later.

When and why does a perpetrator state take a contrite stance on its past wrongs? More specifically, why do Japanese behaviors differ over time in addressing apology and compensation with regard to the comfort women issue? I address these questions by testing two hypotheses using an instrumentalist approach and a transnational-political activism model. The former posits a perpetrator state is more likely to take a contrite stance on its past misdeeds when it calculates such action is in its security and/or economic interests. The latter is a two-level political model. It hypothesizes that when transnational activism is powerful and a perpetrator state is led by a progressive ruling coalition, the state is more likely to adopt conciliatory policies toward historical issues. ${ }^{2}$

I find that the transnational-political activism model possesses more explanatory power than instrumentalism for within-case variations in Japan's behavior toward the comfort women issue. The two approaches are not, however, mutually exclusive and are complementary in some regards. The effect of transnational activism is heightened when the target state is faced with other geopolitical incentives and/or when the target state is led by a progressive ruling coalition and has weak conservative 
reaction. The Japanese state responded to the transnational comfort women movement in a somewhat conciliatory manner between 1993 and 1995 when building better ties with Asia was in its security and economic interests and a liberal, non-Liberal Democratic Party (LDP) coalition briefly took power. During that time period, conservative reaction within Japan was weak as well.

\section{Analytical Frameworks for State History Policy}

Two perspectives seem pertinent to explain a perpetrator state's history policy. The first is an instrumentalist explanation that stresses security and/or economic incentives to adopt a contrite stance on historical issues. The second perspective is the transnational-political activism model that emphasizes the importance of political and societal actors in exerting great influence on state behavior toward historical problems.

\section{Definition and Operationalization of Contrition}

The dependent variable in this study is the variation in state behavior in apology and compensation regarding the comfort women issue. There are three levels of state behavior in addressing apology and compensation issues: deep contrition, shallow contrition, and no contrition. The definition of deep (shallow) contrition is official state behavior that reflects a deep (shallow) sense of remorse for its past violence. But, no contrition means showing no sense of remorse for past wrongs. Therefore, an important criterion to classify these levels is whether a perpetrator state displays a sense of remorse for its past transgressions through its official statements and compensation measures. ${ }^{3}$

Given these definitions, I operationalize the three different levels of contrition in a qualitative manner. When a perpetrator state reaches the highest level, deep contrition, in the area of apology and compensation, the state issues apologetic statements to manifestly acknowledge past wrongs and expresses regret for them to former victims. In these statements, agency is clear (i.e., $X$ did this to $Y$ ) and apologetic words are unambiguous. The state also pays direct compensation to surviving victims for its past offenses. When a perpetrator state is in the next phase, shallow contrition, the state issues apologetic statements, but the contents of these statements are ambiguous enough to raise doubts on the state's sincerity. Statements express remorse but do not fully acknowledge past wrongdoing; or, they reflect remorse yet fail to specify the agency that committed the crimes. Although it makes apologetic statements, the state takes no concrete actions to compensate former victims for its past vio- 
lence in order to fulfill the statements; or, instead of direct state compensation, the state pays victim survivors only indirectly through a nongovernmental fund. When a perpetrator state shows no contrition, the state issues official statements that justify, deny, or glorify its past misdeeds. The state does not mention past violence at all. It does not speak of or design any compensation scheme for surviving victims either. The state may also overlook its past (somewhat) apologetic statements and policies, regressing to more unapologetic attitudes regarding apology and compensation issues.

\section{Instrumentalism}

As an interest-based approach, instrumentalism means here that a perpetrator state's behavior is shaped by calculations of national interests. ${ }^{4}$ As rational actors, perpetrator states should choose history policies that best serve their overall security and/or economic interests (Berger 2012). For perpetrator states, coming to terms with their past wrongs can be used as a means of improving their diplomatic relations with former victim states, which can help avoid diplomatic isolation and thus promote their own security. Perpetrator states also can take a more conciliatory stance on their past misdeeds in order to strengthen their economic ties with former victim states and to gain more economic benefits by doing that. In this regard, it would be important whether or not a perpetrator state has security and/or economic incentives to seek closer ties with its neighboring countries-particularly with former victim states. Given this logic, the following hypothesis is inferred: a perpetrator state is more likely to take a contrite stance on its past misdeeds when it calculates such action is in its security and/or economic interests. The presence of both security and economic incentives will prompt a perpetrator state to take a deeply contrite stance on historical issues, whereas the absence of both incentives will lead it to the level of no contrition. The presence of either security or economic incentives will bring about its reaching the level of shallow contrition.

Since the early 1950 s, Japan's ultimate security interest-national survival - has been largely dependent upon the US-Japan Alliance, which has formed the bedrock of Japan's postwar foreign policy (He 2009, 295). The conclusion of the US-Japan Security Treaty in 1951 ensured Japan's internal and external security by guaranteeing the presence of US troops in Japan (Seraphim 2006, 18-19). This alliance agreement did not require Japan's reconciliation with war-shattered Korea or Communist China. Responding to US pressure, Japan did normalize its relationship with South Korea in 1965. But up until the late 1980s, it was not neces- 
sary for Japan to accommodate South Korea, because Japan was protected by the United States.

The US-Japan Alliance significantly weakened between 1991 and 1995 due to the disappearance of the common enemy, the Soviet Union, and intensified trade disputes between the United States and Japan. As Victor Cha (1999) posits, the fear of US abandonment would compel Japan to improve its relationship with South Korea. However, the period from the mid-1990s witnessed the notable strengthening of the alliance, which was aimed at checking and balancing North Korea's provocative actions and the rising Chinese threat at the time. US war on terrorism after September 11, 2001, also played a key role in invigorating the USJapan security alliance, as Japan became an indispensable supporter of the US policy on terrorism.

In terms of economic interests, Japan did not have to put great value on its Asian neighbors, especially South Korea, until the end of the 1960s. As an advanced and powerful economy in the region, Japan was largely dependent on US and European markets. In the 1970s, however, Japan started to expand its interest in East Asia, and Japan's economic interests in the region increased significantly in the 1980s. Not only did South Korea and Taiwan emerge as economic competitors to Japan, but China also began to focus on economic development after Deng Xiaoping came to power in 1978 (Berger 2012, 165-166). Under these changed circumstances, Japan had to pay more attention to Asia's huge economic potential, especially as US and European markets were turning increasingly protectionist. In this regard, an instrumentalist focus on security and economic incentives enables the following predictions: (1) Japan will take unapologetic attitudes toward historical issues until the late 1960s (in the absence of both security and economic incentives); (2) Japan will take shallowly contrite attitudes toward historical problems in the 1970s1980s and after the mid-1990s (in the presence of economic incentives but no security incentives); and (3) Japan will take deeply contrite attitudes toward the issues during the period between 1991 and 1995 (in the presence of both security and economic incentives).

\section{The Transnational-Political Activism Model}

The transnational-political activism model is a newly synthesized analytical framework that can be represented by a two-by-two matrix addressing how political and societal actors can affect state behavior in dealing with historical issues. According to this model, a progressive governing coalition tends to place more value on human rights and social justice than a conservative ruling coalition (Chang 2008; Huntington 1957; Laak 
2003). Progressive ruling coalitions are more apt to voluntarily initiate processes that address past wrongs and ignore or finesse conservative and nationalist interest groups. They are also more likely to listen to and seriously take into account the voices and requests of transnational activist groups. For progressives, reckoning with historical issues is closely connected with actions that advance their ideological values. Therefore, whether or not a perpetrator state's ruling coalition is progressive exerts significant influence on the state's dealings with apology/compensation issues.

However, conservative governing coalitions, which usually put the first priority on national pride and confidence, strive to prevent their government and society from taking a contrite attitude toward past wrongs. To this end, they often create a broad political network that empowers conservative groups and media. Conservative groups strongly oppose transnational activism or their state's contrite attitudes by participating in a unified network with conservative media, intellectuals, and political figures. Jennifer Lind (2008, 181-186) supports this point indirectly by arguing that contrition often triggers conservative backlash, because many conservatives believe that emphasizing past violence and wrongdoings undermines national pride and patriotism. As Richard Price (2003, 586) points out, the outcomes of transnational activism may vary according to the intensity of a backlash from targets of activism. Margaret Keck and Kathryn Sikkink $(1998,202)$ also highlight how political resistance may interfere with the influence of transnational actors and exert a strong impact on issue resonance.

Along with the nature of ruling coalitions, transnational activist networks play a key role in altering the way a perpetrator state comes to terms with its past actions. To address historical problems, nongovernmental organizations (NGOs) seek to organize a transnational activist network and promote issue resonance in the international community. Progressive civil groups in a perpetrator state tend to join and/or support the transnational activist networks that address apology and compensation issues, as their progressive ideological goals are often compatible with ones of transnational actors. To promote the effectiveness of their activism, furthermore, network actors frequently seek to make connections with the media, international organizations, and other (powerful) states. Through this issue resonance, the transnational network exerts pressure on the state to correct its behavior in a contrite manner (Keck and Sikkink 1998; Price 1998).

For this article, I code the power of transnational activism in dichotomous terms as either strong or weak. I evaluate the strength of transna- 
tional activist networks on the basis of two factors: (1) network density and cohesiveness; and (2) external support from the media, international institutions, and foreign governments. A strong transnational network will engage in regular exchanges between NGOs in a dense, unified network and enjoy a high degree of external support from the media, international organizations, and other governments. A weak transnational network, however, does not have regular exchanges between NGOs within a sparse network. It not only suffers a sharp division among network actors in terms of movement tactics or goals but also shows a low degree of support from the media, international organizations, and governments.

Hence, the transnational-political activism model deduces the following hypothesis, which can be summarized in Figure 1. The combination of the two independent variables - the power of transnational activism and the nature of a ruling coalition-yields four possible outcomes for a perpetrator state's behavior in grappling with historical problems.

First, when strong transnational activism aligns with a progressive ruling coalition in a perpetrator state, the state will take deeply contrite attitudes toward historical problems (quadrant I). The combination of a sympathetic government and strong networks incentivizes NGOs to develop suitable strategies through exchanges like holding conferences and workshops. Drawing attention from the media, international organizations, and other governments, transnational networks are more likely to achieve issue resonance in the international community. In this process,

\section{Figure 1 Transnational-Political Activism Model for State Behavior Toward Historical Issues}

\begin{tabular}{|c|c|c|c|}
\hline \multirow{4}{*}{$\begin{array}{c}\text { Power of } \\
\text { Transnational } \\
\text { Activism }\end{array}$} & \multirow[b]{3}{*}{ Strong } & \multicolumn{2}{|c|}{ Ruling Coalition in Perpetrator State } \\
\hline & & Progressive & Conservative \\
\hline & & I. Deep Contrition & II. Shallow Contrition \\
\hline & Weak & III. Shallow Contrition & IV. No Contrition \\
\hline
\end{tabular}


while ignoring or circumventing conservative and nationalist domestic groups, a progressive governing coalition listens to and seriously takes into account the voices and requests of transnational networks. Through this issue resonance, transnational networks seek to persuade and exert strong pressure on the state to rectify its behavior. The perpetrator state thus takes up deeply contrite attitudes toward historical issues.

Second, when there is strong transnational activism and a perpetrator state is led by a conservative ruling coalition, the state will at most show shallow contrition in addressing historical issues (quadrant II). In this instance, transnational activist networks are able to elevate issue resonance with the support of the media, international organizations, and other foreign governments. This strong transnational activism plays a key role in pushing the state to adopt more apologetic attitudes toward historical matters. However, conservative ruling coalitions can deflect such pressures, in part by empowering conservative interest groups. Strong transnational networks might force marginal concessions from conservatives but will be less successful. As a consequence, the perpetrator state takes shallowly contrite or tactical measures in response to domestic and international pressure.

Third, when weak transnational activism is combined with a progressive governing coalition in a perpetrator state, contrition will also likely be shallow (quadrant III). A progressive ruling coalition listens to and carefully takes into consideration the voices and requests of transnational networks. However, weak transnational networks are unable to enhance issue resonance and thus have no significant impact on state behavior in addressing historical issues. And if conservative organizations actively work, they will face less resistance due to the weak transnational activism. Given this situation, the state, though governed by a progressive ruling coalition, is likely to only achieve shallowly contrite measures or fail to adopt any contrite stance on historical issues due to weak external network pressure.

Finally, when there is weak transnational activism and a perpetrator state is governed by a conservative ruling coalition, the state is unlikely to be contrite at all (quadrant IV). Weak transnational networks fail to promote issue resonance enough to push a perpetrator state to behave in a more contrite manner. Putting much value on state and national pride, a conservative ruling coalition neglects the voices of weak transnational activist networks and conservative groups are empowered. Under such circumstances, the perpetrator state has no incentive to take contrite attitudes toward historical matters. As a result, the state issues official statements denying its wartime crimes and resists compensating for past 
violence. Furthermore, the state may overlook its past apologetic statements and policies, reverting to a more unapologetic stance on the issues.

The subsequent sections test the two analytical frameworks against historical facts with regard to the comfort women issue. During the first phase, from 1945 to 1990 , neither model would predict contrition, although instrumentalism expects shallow contrition in the 1970s-1980s with the rise of Japan's economic incentives. An actual outcome during this first phase was marked by no contrition: Japan showed little care or remorse toward the historical matter. During the second phase, from 1991 to 1995, instrumentalism predicts deep contrition as both Japan's security and economic incentives are strong, while the transnational-political activism model expects shallow contrition. But this period actually consisted of shallow contrition: the Japanese state issued somewhat apologetic statements and established a nongovernmental fund to compensate former comfort women. During the third phase, between 1996 and the mid-2000s, instrumentalism predicts shallow contrition with Japan's security interests significantly weakened, whereas the activism model expects no contrition. As an actual outcome, the Japanese state largely maintained a state of shallow contrition in addressing the comfort women issue, but showed frequent regression to no contrition.

\section{Phase One, 1945-1990: No Contrition}

The Japanese state was not contrite regarding the comfort women issue during this lengthy period. Specifically, the Japanese government did not issue any apologetic statements regarding this issue, ${ }^{5}$ nor did it speak of designing a compensation scheme for the surviving comfort women. This outcome is related to not only the absence of transnational and political actors dedicated to addressing the issue in Japan or victim states, particularly Korea, but also Japan's weak geopolitical incentives to deal with its past transgressions.

\section{The Transnational-Political Activism Model:}

The Absence of Transnational and Political Agents

Postwar Japan was mostly governed by its conservative elites, some of whom were involved in the expansion of imperial Japan, the war against the United States, and wartime crimes. A former Korean foreign minister pointed out Japan's conservative leaders were reluctant to acknowledge their nation's past misdeeds, as it would have posed a threat to their political standing. ${ }^{6}$ It was natural for such leaders to avoid seriously pur- 
suing the issue of who bore responsibility for the war and wartime atrocities. Under the longtime conservative LDP rule, therefore, the Japanese government had no stake in voluntarily addressing the comfort women issue, which could have caused serious damage to its political standing and national pride.

Additionally, the main victim state-Korea - did not initially have the wherewithal to take the comfort women issue into account during this period given the political and social turmoil produced by the unexpected division into the two Koreas after liberation and the ensuing Korean War between 1950 and 1953 (Soh 2008, 168). Korean authoritarian leaders such as Park Jung-hee and Chun Doo-whan were engrossed in accelerating economic development in order to strengthen their weak political legitimacy, including through improving relations with Japan. For instance, President Park did not seriously address historical issues in return for receiving economic assistance from Japan in making the KoreaJapan Normalization Treaty in 1965. Moreover, the patriarchal social atmosphere in Korea, which made sex victims feel ashamed while the assailants were generally tacitly tolerated, also helped prevent former comfort women from publicizing the issue. Hence, this period exactly falls into quadrant IV (weak transnational activism with conservative ruling coalition results in no contrition), as shown in Figure 1.

Instrumentalism: Weak Security and Economic Incentives The Japanese state did not have strong geopolitical incentives to address its past wrongs committed on the Asian mainland, including the comfort women issue, during the early postwar period. In the deepening Cold War, Japan paid much greater attention to the United States than Asia for its security and economic imperatives. Japan's security needs were fully satisfied by the conclusion of the US-Japan Security Treaty in 1951, which guaranteed the presence of US troops in Japan and ensured its internal and external security. In this alliance agreement, Japan was not required to reconcile with war-shattered Korea and Communist China. In the economic arena, Japan's primary trading partner was the United States, although Japan depended on the import of strategic raw materials from other parts of Asia (Berger 2012, 189). Japan quickly became the dominant power in the region. In this context, it had no compelling realpolitik concerns at the time to deal with its past injustices in the Asian theater of World War II.

Furthermore, the 1951 San Francisco Peace Treaty, which formally dissolved Japan's empire and restored its national sovereignty, helped Japan avoid seriously addressing its wartime atrocities in Asia (Lee 
2007). Immediately after World War II, the United States planned to implement a strict reparation policy toward Japan. ${ }^{7}$ This harsh reparation plan, however, was rolled back significantly for three reasons. First, as the Cold War intensified, the US government came to recognize Japan's elevated strategic value in preventing the spread of communism in East Asia. Second, the United States desired to reduce its huge occupational expenses and became concerned that Japan's excessive reparations scheme could further aggravate the US financial condition. Indeed, during the occupation (1945-1952), the US government had to provide Japan with more than $\$ 2$ billion in economic aid. Third, the United States reflected fruitfully on the lessons learned following the excessive reparations regime applied to Germany following World War I, and how it contributed to the emergence of the Nazi regime and the subsequent outbreak of World War II.

With these relaxed conditions, the major Western powers-including the United Kingdom and Australia-renounced their reparation claims following the US example. China and Korea, the nations most severely damaged by Japan's aggressive war and colonial rule, were excluded from the forty-nine official signatories of the San Francisco Peace Treaty. Only Indonesia and a few other Southeast Asian countries requested and received reparations for war damages (Seraphim 2006, 320). In a series of bilateral negotiations with those countries, Japanese negotiators "were able to hammer out ambiguously worded agreements in which they offered economic development assistance that could be interpreted as reparations, without officially having to acknowledge them as such" (Berger 2007, 190). In this process, consequently, Japan was able to avoid directly addressing its past atrocities in Asia, including the comfort women issue.

\section{Phase Two, 1991-1995: Shallow Contrition}

Japan began to change its original position and shifted its stance on the comfort women issue from no contrition to shallow contrition during this second phase. During his state visit to South Korea in January 1992, Prime Minister Miyazawa Kiichi made a formal public apology for Japan's past wrongs. In a speech to South Korea's National Assembly, Miyazawa said, "Recently, the issue of comfort women in the service of the Imperial Japanese Army has come into light. I cannot help feeling acutely distressed over this, and I express my sincerest apology." 8 In the first official investigative report of July 1992, moreover, the Japanese government admitted to the military's involvement in the comfort women 
issue, although it did not acknowledge its forceful recruitment of comfort women. ${ }^{9}$ In August 1993, the Japanese government issued a second official report (the so-called Kono Statement) that partially admitted its involvement in the forceful recruitment of comfort women. ${ }^{10}$

This report, however, failed to acknowledge that the Japanese government and military were the main actors in establishing and managing the comfort women system. ${ }^{11}$ Meanwhile, Prime Minister Murayama, a socialist, made a series of apologetic statements regarding the comfort women issue during this second phase. He commented in July 1995 that "the problem of the wartime comfort women is one such scar, which, with the involvement of the Japanese military forces of the time, seriously stained the honor and dignity of many women. This is entirely inexcusable. I offer my profound apology to all those who, as wartime comfort women, suffered emotional and physical wounds that can never be closed." ${ }^{12}$ Despite these statements, the Japanese government still refused individual compensation for the surviving victims on the ground that "Japan had earlier provided reparations to, or reached agreements with, the governments concerned" (Hayashi 2001, 574). Instead of providing direct state compensation, the government helped establish a nongovernmental fund, the AWF, in July $1995 .^{13}$

Therefore, compared with the first phase, Japan's behavior toward the comfort women issue moved significantly toward a more contrite stance during this second period between 1991 and 1995, although it did not achieve deep contrition. This shift in behavior could be related to both powerful transnational activism led by societal groups in South Korea/Japan and the brief rule of a progressive coalition government. This second phase also witnessed a rise in Japan's geopolitical incentives to address its past misdeeds following the end of the Cold War. However, instrumentalism cannot fully explain why Japan did not go further toward a deep contrition, given strong realpolitik concerns.

\section{Instrumentalism: Strong Security and Economic Incentives}

As noted, the Japanese state made progress regarding apology and compensation linked to the comfort women issue, although it stopped short of accepting full culpability and providing direct state compensation. This progress can to some extent be explained by the strong geopolitical incentives that had developed and made Japan more likely to address its past wrongs. As a professor at Tokyo University notes, Japan was no longer able to overlook its Asian neighbors in pursuing its own security, economic, and political interests following the end of the Cold War in 1989. ${ }^{14}$ From a strategic standpoint, the significant weakening of the US- 
Japan Alliance in the early 1990s, which had been the bedrock of Japan's postwar foreign policy, can be construed as a clear motive for Japan's seeking closer ties with other Asian countries (Mochizuki 2007, 4). The 1990-1991 Gulf War first caused a rupture in the US-Japan Alliance. As the United States led efforts against Iraq to liberate Kuwait, Washington demanded a military contribution from Japan commensurate with their alliance partnership. Despite this request, Japan provided a large sum of financial support ( $\$ 13$ billion) rather than dispatching its Self-Defense Forces (SDF) and cited the Peace Constitution that prevented the movement of troops overseas. Despite the hefty financial contribution, Japan received little gratitude and recognition from the United States or Kuwait following the Gulf War (Park 2004, 177).

The US-Japan Alliance faced other challenges in the early 1990s. Given the disappearance of a common adversary, the Bush administration began to place increased weight on economic issues while it deemphasized Japan's strategic importance (Park 2007, 187-188). At the end of Bush's presidency, the US Department of Defense issued a strategic report that took into account the reduction of the US military presence in Asia. President Clinton, who was inaugurated in 1993, also focused on economic diplomacy and strove to rectify the trade imbalance between the United States and Japan. Thus the US trade representative and the National Economic Council officials were much more influential than the security experts who had enjoyed greater influence when maintaining a containment policy had been a critical driver to US-Japan relations. Moreover, Japanese concerns were further aroused when the United States labeled China a strategic partner. To Japan, this action signaled a significant devaluation of the US-Japan Alliance. With the emergence of Asia's huge economic potential, Japan also faced another economic challenge: "the rise of economic regionalism, such as the formation of a unified European market and the North American Free Trade Agreement, which could hamper Japan's access to lucrative markets in the advanced industrial world" (Mochizuki 2007, 4). Japan thus needed to better integrate itself with Asia by mending bridges that had remained in disrepair long after the conclusion of World War II-era hostilities. Facing these new concerns and challenges, Japanese leaders recognized the US-Japan Alliance was no longer sufficient and that Japan needed to take proactive steps to nurture a favorable environment in Asia to protect its long-term security and economic interests. ${ }^{15}$

Accordingly, instrumentalism can provide a plausible explanation of the positive changes in Japan's dealings with the comfort women issue during this second phase. Instrumentalism is not sufficient, however, to 
account for why Japan did not go further toward a deep contrition, given the geostrategic gains. Rather the answers are to be found in the interaction of transnational networks and domestic politics. As described above, Japan refused to accept full state responsibility for the issue as evidenced by its establishment of a nongovernmental fund. A reason for the Japanese government's wan response was that despite strong networks, the rule of a progressive non-LDP coalition was short. And, even during that period, the still-influential conservative LDP prevented a progressive Prime Minister Murayama from adopting deeply contrite measures toward the historical matter.

\section{Strong Transnational Comfort Women Movement}

The Korean Council for the Women Drafted for Military Sexual Slavery by Japan (hereafter the Korean Council) played a key role in launching and strengthening a transnational movement aimed at redressing the comfort women issue. Thanks to the Korean Council's efforts, a Korean victim-Hak-sun Kim-first delivered public testimony on her ordeal in August $1991 .{ }^{16} \mathrm{Kim}$ 's testimony, reported by news media, attracted much attention from the Japanese public, notably promoting the cooperation of many Japanese groups with the Korean Council. Among these groups were the Association of Japanese Women, the Young Women's Christian Association, the National Council of Churches in Japan, and the Asian Women Association (Chung 2001, 167-168). In December 1991, Kim and two other victims also filed a class-action lawsuit against the Japanese government, requesting 20 million yen each. Furthermore, the uncovering of official documents in Japan strengthened the transnational comfort women movement. The national daily Asahi Shimbun reported this discovery of the official documents on January 11, 1992, notably increasing public interest in the comfort women issue (Seaton 2006). These documents proved the Japanese government had been involved in establishing and managing the military comfort women system.

The Korean Council strove to publicize the comfort women issue internationally by appealing to the UN Human Rights Commission in March 1992 (Soh 2003). To build solidarity, furthermore, the Korean Council paid great attention to networking with women's organizations in other Asian countries whose women had suffered. The first Asian Women's Solidarity Forum was held in Seoul in August 1992 under the auspices of the Korean Council. Victims and support groups from Asian nations, including the Asian Center for Women's Human Rights in the Philippines and the Taipei Women's Rescue Foundation, attended the regional conference that formalized a transnational network dedicated to 
the comfort women issue (Yoon 2007, 29). In the wake of this forum, there was an upsurge of cooperation among groups in the countries of victims and groups in Japan.

These newly networked groups actively sought to raise the comfort women issue in international conferences sponsored by the UN. During the 1993 World Conference on Human Rights in Vienna, the Asian Women's Forum was launched and adopted a resolution demanding the UN investigate the Japanese army's sexual slavery system. ${ }^{17}$ Representatives from the Asian groups frequently participated in preliminary meetings for the 1995 World Conference on Women in Beijing and worked as lobbyists publicizing the seriousness of suffering inflicted on former comfort women. ${ }^{18}$ As a result of their efforts, the Vienna Conference clearly included "sexual slavery" as a violation of women's human rights under armed conflict in the Vienna Declaration. In its code of conduct, the Beijing Conference stipulated that as sexual slavery was a war crime, perpetrator states should investigate allegations, punish the persons in charge, and compensate surviving victims. Consequently, this mobilized transnational activism significantly increased issue resonance in the international community, thus pushing the Japanese government to move toward a more contrite stance on the comfort women issue.

In contrast to this strong transnational activism, Japan's conservative groups were caught off guard and unprepared for mounting a defense during this second phase. As Sarah Soh $(2008,66)$ notes, "Conservatives regarded the comfort women redress activism through a small number of NGOs as noise that over time would fade away." Japanese nationalists just expressed their negative opinions of the transnational comfort women movement and the somewhat apologetic stance of the Japanese government regarding the issue. In an editorial, the Sankei Shimbun lamented that Japan had to take the blame in the sense that countries like Britain also employed foreign prostitutes throughout its empire (Seaton 2006, 110). Japanese conservative figures usually asserted that the military comfort women issue was not only a necessary evil at the time but also an effective system aimed at protecting women in Japan's occupied territories (Chung 2001, 175).

\section{The Brief Rule of a Progressive Ruling Coalition}

The second phase witnessed the emergence of a progressive non-LDP coalition and the first socialist prime minister since 1948, offering a window of opportunity to come to terms with Japan's past. ${ }^{19}$ In contrast to the long-ruling conservative LDP, they strove to address Japan's injustices committed in Asia during World War II, thus being more responsive 
to the requests of transnational activist groups. Upon taking office in August 1993, Prime Minister Hosokawa Morihiro made an unprecedented remark that characterized Japan's past actions in Asia as an "aggressive war" and "wrong war." In another speech, he also named Japan's presence in Korea as "colonial rule" rather than using the conventional euphemism of "annexation" (Nozaki 2005, 292). As noted before, Prime Minister Murayama sincerely expressed a sense of contrition for Japan's past violence to its Asian neighbors.

Despite these positive changes, however, the Japanese state failed to move toward the level of deep contrition due to strong opposition from conservative politicians (Lind 2008, 75-77). Reacting to Hosokawa's remarks, a group of conservative LDP politicians organized the Committee for the Examination of History, which campaigned to foster views of history that recognized World War II as justifiable and denied the existence of the military comfort women (Nozaki 2005, 293). Prime Minister Murayama sought to adopt an "antiwar resolution" or an "apology resolution" marking the fiftieth anniversary of Japan's surrender. This endeavor was also confronted with opposition from conservative politicians in Japan. To prevent passage of the Diet resolution, in December 1994 about half of LDP members established a conservative organization known as The Diet Members League for the Fiftieth Anniversary of the End of World War II (McCormack 2000, 56). Given this opposition from the LDP - the dominant coalition partner-Murayama had no choice but to accept a compromised statement, which was an ambiguous statement that satisfied no one, in order to avoid the risk of ending up with no resolution at all (Saaler 2005, 72-73). And under this strong conservative influence, the Japanese government only helped establish a nongovernmental fund, the AWF, instead of providing direct state compensation for former comfort women. Therefore, the second phase falls broadly into quadrant II as shown in Figure 1. Although the issue did see a strong transnational network and progressive government, the progressive government did not last long and was constrained by ongoing LDP opposition.

\section{Phase Three, 1996-mid-2000s: Shallow Contrition and No Contrition}

Between 1996 and the mid-2000s, the Japanese state maintained its shallow contrition regarding the comfort women issue, though the period was also marked by frequent regression to unapologetic attitudes. During this third phase, the Japanese government generally reaffirmed Prime 
Minister Murayama's apologetic statement of 1995. In October 1998, for instance, Prime Minister Obuchi Keizo expressed his deep remorse and heartfelt apology, stating that Japan caused tremendous damage and suffering to Korean people during a certain period in the past. ${ }^{20}$ Prime Minister Koizumi Junichiro also issued apologetic statements in an official letter sent to the former comfort women in 2001. ${ }^{21}$ The Japanese state also carried out its nongovernmental compensation project through the Asian Women's Fund during this period. Despite the pressure from transnational actors, however, the Japanese government declined to directly pay individual compensation.

Frequent regression to unrepentant attitudes also marked this period. First, Prime Minister Hashimoto Ryutaro was reportedly reluctant to send apologetic letters to former comfort women in 1996 (Onuma 2007, 75-76). Second, high-ranking Japanese government officials countered the previous apologetic statements by making a series of blunders that attempted to justify or gloss over Japan's past wrongs. For example, LDP politician Okuno Seisuke commented twice in June and July 1996 that "comfort women voluntarily participated in commercial transactions and they were managed by businesses" (Yang 2008, 79). Third, the Japanese government also exerted pressure on the Japan Broadcasting Corporation (Nippon Hōsō Kyōkai, NHK) not to air documentaries showing its involvement in the wartime sex slave system (Morris-Suzuki 2005, 5). A Japanese journalist points out the NHK aired many TV programs dealing with Japan's wartime responsibilities in the 1970s and 1980s. NHK television producers, however, could not easily make such programs under pressure from the conservative LDP-led governing coalition from the late 1990s. ${ }^{22}$ Finally, in March 2007 Prime Minister Abe Shinzo stated, "there was no evidence to support the initially accepted notion that coercion was used by the Japanese military or government in recruiting wartime comfort women" (Yang 2008, 74-75).

A cause of Japan's retrogressive stance on the comfort women issue lay in the rise of the strong conservative, nationalist forces and the conservative LDP-led coalition government.

Japanese conservative groups produced a strong backlash and dampened the transnational comfort women movement significantly. A newly emerged, conservative LDP-led coalition had no incentives to take contrite attitudes toward historical issues. The ruling coalition thus neglected the voices of transnational activist networks and reverted to a more unapologetic stance on apology and compensation. This third phase was also marked by strong economic incentives but weakened security incentives to grapple with past wrongs in the Asian mainland. 
Instrumentalism: Strong Economic Interests but

Weakened Security Interests

This third phase saw that Japan's economic incentives to address past wrongs continued, but its security incentives decreased, especially after Prime Minister Koizumi took power in 2001. Due to burgeoning Japanese interests in Asian markets, Japanese business leaders strongly urged the Japanese government to tackle unresolved issues regarding the past (Berger 2012, 177-178). However, the notable strengthening of the USJapan Alliance since the mid-1990s had largely satisfied Japan's heightened security concerns, thus weakening Japan's need to improve its ties with Asia.

Japan benefited from a significant strengthening in the US-Japan Alliance during this third phase. The 1994 North Korean nuclear crisis was a major catalyst for this development, as North Korea's nuclear adventurism prompted the United States and Japan to seriously reevaluate their existing bilateral security alliance (Soeya 2006, 127-129). Japanese authorities perceived Japan had no constitutional measure allowing the Self-Defense Forces to provide US troops with the rear support that would be necessary in any number of potential regional contingencies. US authorities also recognized Japan's strategic importance in order to better cope with contingent situations on the Korean peninsula that would cause the sacrifice of numerous US soldiers. The United States desired to strengthen the alliance with Japan and reconfirmed its security commitment in Asia. As a subsequent measure, the two countries announced a new US-Japan Joint Declaration on Security in April 1996, which redefined the bilateral alliance as a regional alliance for maintaining security and prosperity in the Asia-Pacific region. ${ }^{23}$ A series of subsequent incidents, including the 1996 Taiwan Strait crisis and the 1998 launch of a North Korean Taepodong missile over Japan, reinforced the US-Japan security alliance during this period, further weakening Japan's motives for seeking closer ties with Asian countries (Park 2007, 191).

The September 11, 2001, terrorist attacks on the United States served as another catalyst to reinforce the US-Japan Alliance (Park 2007, 193). Following this incident, the United States focused on a security strategy to fight against terrorism and to prevent the proliferation of weapons of mass destruction. To this end, the United States needed strong support from one of its main alliance partners-Japan. By the same token, recognizing the US position, the Japanese government paid greater attention to establishing stronger cooperative ties with the United States. In response to the US war against Iraq in March 2003, the Koizumi administration immediately declared its support for the war and promised to 
dispatch the SDF to Iraq. In contrast to the prior phase, therefore, it was not necessary - for security reasons at least-for Japan to actively address its past wrongs with other Asian nations, as the notably strengthened US-Japan Alliance settled the security concerns that Japan had held in the early 1990s.

\section{Relatively Weakened Transnational Activism}

With the above security reasons, the transnational-political activism model can well explain the frequent regression during this third phase. Japanese conservative groups produced a strong backlash and dampened the transnational comfort women movement significantly. A newly emerged, conservative LDP-led coalition had no incentives to take contrite attitudes toward historical issues. The ruling coalition thus neglected the voices of transnational activist networks and reverted to a more unapologetic stance on apology and compensation with regard to the comfort women issue.

During this third phase, the transnational comfort women movement was challenged by a sharp division among its component groups. The split among the communities of victim survivors and their supporters became distinct following the creation of the Asian Women's Fund in July 1995. According to a Japanese civic activist, "The AWF was a major cause of the division within the progressive camp in Japan. The establishment of the non-governmental fund was not an appropriate action because it was not direct state compensation for the suffering of former comfort women." 24 Many activist groups that had persistently requested state compensation were vehemently opposed to the establishment of the AWF because they regarded it as an attempt by the Japanese government to avoid its legal responsibilities. A variety of Japanese groups also formed a unified organization called the Executive Committee for Destructing AWF, campaigning against the AWF through street rallies of protest, a signature-collecting movement, and international conferences. Nevertheless, many of Japan's prominent activists and organizations supported the formation and activities of the AWF (Chung 2001, 179-181). The primary reason for these groups' support was 'to take some concrete action for elderly survivors before they died without receiving any tokens of atonement, let alone legal compensation" (Soh 2003, 224).

The fissures among these groups began to wane in 1998 when the Korean government paid an equivalent amount of atonement money (about $\$ 26,000$ ), suggested by the AWF, to each survivor (Soh 2003, 228-230). Such payment was conducted under the condition that the recipients would not accept AWF money. Given this circumstance, the in- 
fluence of groups that had supported the AWF was weakened in Japan and abroad. The anti-AWF groups continued to lobby the Japanese Diet for reparation laws (Mitsui 2007, 46). A variety of legal groups and the Campaign for Completing Postwar Compensation prepared reparation bills for the Japanese Diet. After organizing a citizen convention, moreover, a number of groups such as the Violence Against Women in War Network, Japan (VAWW-NET Japan) sought to constitute a fact-finding bill to demand the Japanese Diet's research regarding Japan's comprehensive war responsibility, including the comfort women issue. These legal approaches were not successful, but transnational groups, including the Postwar Compensation Network, continuously lobbied Japanese politicians, particularly Democratic Party of Japan (DPJ) Diet members, to enact reparation laws. ${ }^{25}$

\section{Mobilized Conservative Reaction with an LDP-Led Coalition}

Beginning in 1996, Japanese conservatives/nationalists launched a systematic counterattack against the transnational comfort women movement and the Japanese government's softening stance on the issue. In right-leaning magazines, nationalists published a number of articles arguing Japan's imperial war was not wrong in the context of world history at the time (Chung 2001, 140-147). They even asserted the comfort women system had been a good institution that prevented local women from being raped. At the center of these systematic nationalistic campaigns was the Research Association of Liberal Historical Perspectives founded by Tokyo University professor Fujioka Nobukazu in February 1995. The Research Association emerged primarily in response to the official history textbooks released in 1994 that included the descriptions of Japan's past wrongs, including comfort women, Unit 731, and the Nanjing Massacre (Kim 2008, 103). The Research Association aimed to remove all mentions of comfort women from the textbooks in order to recover Japan's damaged national pride. It attacked the textbooks' content, claiming that "comfort women were protected and well treated, not exploited by the Japanese military and government authorities" (Hayashi 2001, 576).

In support of this movement, the Sankei Shimbun published a series of articles titled "What the School Textbooks Do Not Teach," written by Research Association authors. Additionally, in its daily editorials the Sankei launched a campaign to eliminate comfort women-related content from history textbooks (Chung 2001, 143). The nationalist backlash in Japan reached its pinnacle in January 1997 when nationalist LDP members and conservative academics such as Fujioka founded the Japanese 
Society for Composing New History Textbooks (hereafter Tsukurukai). With strong political support from a newly emerged LDP-led coalition, the Tsukurukai engaged in active public outreach programs, publishing many books and holding symposia/conferences, in order to promote conservative perspectives that emphasized Japan's positive historical views and national pride (Saaler 2005, 80-81). The Tsukurukai boasted a significant membership (peaking at 10,000 in 1999) and received strong support from a wide array of prominent figures in Japanese society, including scholars, columnists, art historians, businessmen, and politicians. The Tsukurukai was also able to obtain a wider societal influence because of strong support from Japan's nationalist media, including the Fuji Television Network and the Sankei Shimbun. This strong conservative reaction significantly weakened the effect of the transnational comfort women movement. Therefore, this third phase exactly falls into quadrant IV (weak transnational activism + conservative ruling coalition $=$ regression to no contrition), as illustrated in Figure 1.

\section{Conclusion}

To examine the variations in Japan's choice of history policy, I have tested two competing approaches-instrumentalism and the transnationalpolitical activism model-against the comfort women issue. The former posits that when geopolitical incentives are strong, a perpetrator state is more likely to take contrite attitudes toward historical issues. The latter hypothesizes that when the power of transnational activism is strong and a perpetrator state is led by a progressive ruling coalition, the state is more likely to adopt contrite policies toward historical issues. Table 1 illustrates the results of theory tests regarding Japan's dealings with the comfort women issue.

Table 1 Summary of Theory Tests: Japan Comfort Women

\begin{tabular}{lccc}
\hline & \multicolumn{2}{c}{ Predictions } & \\
\cline { 2 - 3 } & Intrumentalism & T-P Activism Model & Outcomes \\
\hline $1950 \mathrm{~s}-1960 \mathrm{~s}$ & No contrition & No contrition & No contrition \\
$1970 \mathrm{~s}-1980 \mathrm{~s}$ & Shallow contrition & No contrition & No contrition \\
$1991-1995$ & Deep contrition & Shallow contrition & Shallow contrition \\
$1996-$ mid-2000s & Shallow contrition & No contrition & $\begin{array}{c}\text { Shallow contrition } \\
\text { and no contrition }\end{array}$ \\
& & &
\end{tabular}


As can be seen, the theories sometimes predict the same outcome. But when they don't, this study finds the transnational-political activism model is more accurate than instrumentalism in explaining within-case variations in Japan's behavior toward apology and compensation with regard to the comfort women issue. In addition, the activism model can adequately explain the causal mechanisms at work: the dynamics of specific agents-i.e., transnational networks, conservative groups, and ruling coalitions-in affecting state behavior toward historical issues. However, the two approaches are not mutually exclusive and are complementary in some respects. Empirical evidence suggests the effect of transnational activism becomes stronger when the target state has geopolitical incentives and/or when the target state is ruled by a progressive ruling coalition. For example, the Japanese state responded to the transnational comfort women movement in a somewhat contrite manner between 1992 and 1995 when improving its relationships with Asian neighbors was in its security and economic interests and a liberal, nonLDP coalition briefly took power.

This study also finds transnational civil society groups can play a pivotal role in pushing perpetrator states to adopt more apologetic attitudes toward their past injustices. Japan has not taken proactive steps to pay compensation for its past wrongs before victims or organizations representing the victims seriously raised the issues. The Korean Council took the lead in organizing a transnational network focusing on comfort women, elevating the resonance of the issue in the international community and exerting significant pressure on the Japanese government to respond to this unresolved historical matter. However, the conservative LDP-led coalition often deflected such transnational pressure, although the previous short-lived progressive ruling coalition tried to accommodate the voices of transnational networks. Moreover, conservative organizations in Japan, such as the Tsukurukai, significantly dampened the effect of the transnational comfort women movement with the support of conservative media and leaders.

This study indicates that it would be hard for the Japanese state to take a more contrite stance on apology/compensation issues if Japanese society continues to move in a conservative direction. Although the DPJ was relatively more progressive than the LDP, the former was still comprised of many conservative Diet members. For instance, DPJ prime minster Noda (September 2011-December 2012) was more conservative than many LDP politicians in dealing with historical issues. He said, "there are no documents or testimonies on the Japanese side that confirm the comfort women were coerced." 26 Thus despite the rule of a more progressive party, the 2009-2012 period in Japan did not witness any 
significant changes in the Japanese stance on historical issues, including the comfort women issue. During this period, the transnational comfort women movement was continually dampened by powerful conservative reaction in Japanese society, although the transnational networks stayed intact.

Furthermore, while taking an unapologetic stance on the issue of former comfort women, the currently conservative Abe administration reviewed the process of formulating the Kono Statement in June 2014 and announced that the statement was made by a political compromise between the two governments. ${ }^{27}$ This act significantly tarnished the meaning of the Kono Statement, which in 1993 acknowledged Japan's involvement in the forced mobilization of comfort women for the first time. In response, the transnational network, led by the Korean Council, and even the South Korean government harshly criticized such provocative action by the Abe government. However, such external pressure has not worked well. Given the particularly nationalist government on the issue, therefore, conservative forces were empowered and liberal ones weakened, reducing the ability of even strong transnational networks to operate.

Yangmo $K u$ is assistant professor of political science and director of the International Studies Program at Norwich University, Northfield, Vermont. His research focuses on the politics of memory and reconciliation in East Asia and Europe, East Asian security, economic reform in communist states, and US foreign policy making. His work has appeared in Pacific Focus, Asian Perspective, Yale Journal of International Affairs, and Journal of Educational Media, Memory, and Society as well as an edited volume, Routledge Handbook of Memory and Reconciliation in East Asia (forthcoming). He previously taught in the School of International Service at American University and received his $\mathrm{PhD}$ in political science from George Washington University.

\section{Notes}

This research was supported by the Korea Foundation and Norwich University.

1. The term comfort women is a euphemism for women drafted for military sexual slavery by Japan during the Asia Pacific War. I use the term in this article, because scholars have commonly used it in their works.

2. In this article, transnational activism is defined as "voluntary collective action across state borders that self-organized advocacy groups undertake in pursuit of what they deem to be the wider public interest" (Price 2003). A ruling coalition is equal to ruling parties (or a ruling party) that constitute(s) and lead(s) a national government.

3. The concept of contrition in this article is narrower than one adopted in previous studies, as the scope of this research is limited to apology/compensation issues. To measure degrees of contrition reflected in official historical narratives 
(or policies of remembrance), Thomas Berger (2012) and Jennifer Lind (2008) incorporated three more indicators - legal trials, commemoration, and history education - in addition to the official statements and compensation measures.

4. Both realism and neoliberalism can fall into the category of instrumentalism in that those theories endorse the following assumption: as key actors in world politics, states rationally act in accordance with self-interest under the anarchic international system (Katzenstein, Keohane, and Krasner 1998).

5. It was necessary for Japan to soothe Koreans' strong anti-Japanese sentiment that had consistently prevented the making of the Korea-Japan Normalization Treaty. To this end, Japanese foreign minister Shiina issued a somewhat apologetic statement about Japan's colonial rule over Korea when he visited Seoul in January 1965. However, he did not mention any of Japan's past wrongs such as the comfort women issue (Lee 1996, 26-63).

6. Personal interview, Seoul, October 7, 2008.

7. This planned policy intended (1) to transfer to the Allies capital facilities that could make Japan remilitarized; (2) to collect the reparations in kind to the extent that they did not obstruct the subsistence level of the Japanese people or the maintenance of the Allied occupation; and (3) to transfer Japan's overseas property to the Allies (Lee 2007).

8. Seoul Shinmun, January 18, 1992.

9. Ministry of Foreign Affairs of Japan (1992), "Statement by Chief Cabinet Secretary Koichi Kato on the Issue of the So-Called "Wartime Comfort Women' from the Korean Peninsula." www.mofa.go.jp/policy/postwar/state 9207.html (accessed January 5, 2009).

10. Ministry of Foreign Affairs of Japan (1993), "Statement by the Chief Cabinet Secretary Yohei Kono on the Result of the Study on the Issue of 'Comfort Women." www.mofa.go.jp/policy/women/fund/state9308.html (accessed January 5, 2009).

11. Personal interview, Tokyo, October 25, 2008. A Japanese civil activist states, "The report was not fully apologetic because it did not clearly present who had established the system."

12. Ministry of Foreign Affairs of Japan (1995), "Statement by Prime Minister Tomiichi Murayama on the Occasion of the Establishment of the 'Asian Women's Fund." www.mofa.go.jp/policy/women/fund/state9507.html (accessed January 5, 2009).

13. To implement this atonement project, the AWF contained the following three major elements: (1) to provide "atonement money" ( 2 million yen per person) donated by the Japanese people to former comfort women; (2) to send a letter from the Japanese prime minister to surviving victims; and (3) to disburse "about 830 million yen from government funds over a five-year period for victims' medical care and welfare" (AWF 2007, 125).

14. Personal interview, Tokyo, October 16, 2008.

15. For instance, "Powerful factional leaders such as Ozawa Ichiro recognized that Japan needed to address the history question more clearly and directly than it had been willing to do in the past if it were to become more engaged in world affairs" (Berger 2007, 195). 
16. Hankyǒreh, August 15, 1991.

17. Hankyǒreh, June 20, 1993.

18. Chosun Daily, August 24, 1995.

19. The LDP sustained its parliamentary dominance for thirty-eight years until 1993. The Japan Socialist Party (JSP) participated in a brief non-LDP rule from 1993 to 1994 and later formed a coalition government with the LDP under JSP prime minister Murayama Tomiichi between 1994 and 1996.

20. Ministry of Foreign Affairs of Japan (1998), "Japan-Republic of Korea Joint Declaration: A New Japan-Republic of Korea Partnership Towards the Twenty-first Century." www.mofa.go.jp/region/asia-paci/korea/joint9810.html (accessed January 15, 2009).

21. Ministry of Foreign Affairs of Japan (2001), "Letter from Prime Minister Junichiro Koizumi to the Former Comfort Women." www.mofa.go.jp/policy/women/fund/pmletter.html (accessed January 15, 2009).

22. Personal interview, Tokyo, October 21, 2008.

23. Daily Yomiuri, April 18, 1996; Daily Yomiuri, September 23, 1997. They also established the New Guidelines for US-Japan Defense Cooperation in September 1997 that stipulated concrete cooperation measures between US forces and the SDF.

24. Personal interview, Tokyo, October 25, 2008.

25. Personal interviews, Tokyo, October 27, 31, 2008.

26. Available at http://ajw.asahi.com/article/asia/korean_peninsula/AJ2012 08290036 (accessed May 3, 2014).

27. Available at www.japantimes.co.jp/opinion/2014/06/25/editorials/stop -undermining-kono-statement/\#.VL69NUtGj1o (accessed January 20, 2015).

\section{References}

Asian Women's Fund. 2007. The Comfort Women Issue and AWF. Tokyo: AWF. Berger, Thomas. 2007. "The Politics of Memory in Japanese Foreign Relations." In Japan in International Politics: The Foreign Policies of an Adaptive State, ed. Thomas Berger, Mike Mochizuki, and Jitsuo Tsuchiyama. Boulder: Lynne Rienner Publishers.

- 2012. War, Guilt, and World Politics After World War II. New York: Cambridge University Press.

Cha, Victor. 1999. Alignment Despite Antagonism: The US-Korea-Japan Security Triangle. Stanford: Stanford University Press.

Chang, Insung. 2008. "Chŭnhu Ilbon ŭi bosujuŭi wa kukka pyosang” [Postwar Japan's conservatism and state representation]. Paper presented at the Institute for Japanese Studies' workshop on postwar Japan's conservatism, Seoul National University.

Chung, Chin-sung. 2001. Hyundae Ilbon ŭi sahoe undongron [Social movements in modern Japan]. Seoul: Nanam Publishing House.

Chung, Eun-jung. 2004. "Hanil Chogukjǒk Onghomang e kwanhan Yǒngu” [The study of Korea-Japan transnational advocacy network]. Master's thesis, Kyunghee University. 
Hayashi, Hirofumi. 2001. "The Japanese Movement to Protest Wartime Sexual Violence: A Survey of Japanese and International Literature." Critical Asian Studies 33, 4: 572-580.

$\mathrm{He}$, Yinan. 2009. The Search for Reconciliation: Sino-Japanese and GermanPolish Relations Since World War II. New York: Cambridge University Press.

Huntington, Samuel. 1957. "Conservatism as an Ideology." American Political Science Review 51, 2: 454-473.

Katzenstein, Peter J., Robert O. Keohane, and Stephen D. Krasner. 1998. "International Organization and the Study of World Politics." International Organization 52, 4: 645-685.

Keck, Margaret E., and Kathryn Sikkink. 1998. Activists Beyond Borders: Advocacy Networks in International Politics. Ithaca, NY: Cornell University Press.

Kim, Mikyoung. 2008. "Myths, Milieu, and Facts: History Textbook Controversies in Northeast Asia." In East Asia's Haunted Present: Historical Memories and the Resurgence of Nationalism, ed. Hasegawa Tsuyoshi and Togo Kazuhiko. Westport: Praeger Security International.

Laak, Dirk. 2003. "From the Conservative Revolution to Technocratic Conservatism." In German Ideologies Since 1945: Studies in the Political Thought and Culture of the Bonn Republic, ed. Jan-Werner Muller. New York: Palgrave Macmillan.

Lee, Won-deog. 1996. Han-Il Kwagǒsa ch'óri üi wŏnjŏm: Ilbon ŭi chŏnhuch'ŏri oegyo wa Han- Il hoedam [Starting point for settlement of Korea-Japan past history]. Seoul: Seoul National University Press.

_. 2007. "Ilbon ŭi jeonhu chǒri oekyo yǒngu: Dae Asia Jeonhu Baesang Jeongchaek ŭi Gujo wa Hamŭi” [The study of Japan's postwar settlements diplomacy: Structure and implications of Japan's postwar reparation policy toward Asia]. Ilbonhak yǒngu [Japanese studies] 22: 381-409.

Lind, Jennifer. 2008. Sorry States: Apologies in International Politics. Ithaca: Cornell University Press.

McCormack, Gavan. 2000. "The Japanese Movement to Correct History." In Censoring History: Citizenship and Memory in Japan, Germany, and the United States, ed. Laura Hein and Mark Selden. Armonk, NY: M. E. Sharpe.

Mitsui, Hideko. 2007. "The Resignification of the Comfort Women Through NGO Trials." In Rethinking Historical Injustice and Reconciliation in Northeast Asia, ed. Giwook Shin, Soonwon Park, and Daqing Yang. New York: Routledge.

Mochizuki, Mike. 2007. “Japan's Changing International Role.” In Japan in International Politics: The Foreign Policies of an Adaptive State, ed. Thomas Berger, Mike Mochizuki, and Jitsuo Tsuchiyama. Boulder: Lynne Rienner Publishers.

Morris-Suzuki, Tessa. 2005. "Free Speech-Silenced Voices: The Japanese Media and the NHK Affair." Asia Rights 4, 5.

Nozaki, Yoshiko. 2005. "Japanese Politics and the History Textbook Controversy, 1945-2001." In History Education and National Identity in East Asia, ed. Edward Vickers and Alisa Jones. New York: Routledge. 
Onuma, Yasuaki. 2007. Ilbon eun Sajoe hago sipda: Ilbonkun Yianbu Munche wa Asia Yeosóng Kigeum [Japan wants to apologize: The comfort women issue and the Asia Women's Fund]. Seoul: Chonryak kwa Munhwa.

Park, Cheol Hee. 2004. "Jeonsu bangwi esǒ jeokkuk bangwi ro: Miil Dongmaeng mit Wihyup Insik ui Byunhwa wa Ilbon Bangwi Jeongchaek ŭi Jeongchi" [From comprehensive security to active security: The change of the US-Japan Alliance and threat perception, and the politics of Japan's security policy]. Kukje jeongchi nonchong [Journal of international politics] 44: 1 .

2007. “Japanese Strategic Thinking Toward Korea." In Japan's Strategic Thought Toward Asia, ed. Gilbert Rozman. New York: Palgrave.

Piper, Nicola. 2001. "Transnational Women's Activism in Japan and Korea: The Unresolved Issue of Military Sexual Slavery." Global Networks 1, 2: 155170.

Price, Richard. 1998. "Reversing the Gun Sights: Transnational Civil Society Targets Land Mines." International Organization 52, 3: 613-644.

_. 2003. "Transnational Civil Society and Advocacy in World Politics." World Politics 55: 579-606.

Saaler, Sven. 2005. Politics, Memory and Public Opinion: The History Textbook Controversy and Japanese Society. Tokyo: German Institute for Japanese Studies.

Seaton, Philip. 2006. "Reporting the Comfort Women Issue, 1991-1992: Japan's Contested War Memories in the National Press." Japanese Studies 26, 1: 103-105.

Seraphim, Franziska. 2006. War Memory and Social Politics in Japan, 1945-2005. Cambridge: Harvard University Press.

Soeya, Yoshihide. 2006. Ilbon ǔi Mideul Pawo Oekyo: Chŏnhu Ilbon ui Sŏntaek kwa Kusang [Japan's middle power diplomacy: Postwar Japan's choice and idea]. Seoul: Ohreum.

Soh, Sarah. 2003. "Japan's National/Asian Women's Fund for Comfort Women." Pacific Affairs 76, 2: 209-233.

- 2008. The Comfort Women: Sexual Violence and Postcolonial Memory in Korea and Japan. Chicago: University of Chicago Press.

Yang, Kiwoong. 2008. "South Korea and Japan's Frictions over History: A Linguistic Constructivist Reading." Asian Perspective 32, 3: 59-86.

Yoon, Mihyang. 2007. "Ilbonkun Wianbu Munche Haegyǒl ŭl wihan Asia Yǒndae 15 Nyǒn” [Fifteen-year Asian solidarity for resolving Japan's military comfort women issue]. In Chǒngdaehyǒp Charyojip [The Korean Council's sourcebook], ed. Korean Council.

Yoshimi, Yoshiaki. 2000. Comfort Women: Sexual Slavery in the Japanese Military During World War II. New York: Columbia University Press. 


\section{Will This Be China's Century? A Skeptic's View}

\section{Mel Gurtov}

c $\triangle$ research-rich, cogent skeptic's 1 challenge to the premise of many China scholars." -Choice

"A crisp and insightful meditation on the implications of a rising China." -John Delury, Global Asia "Gurtov ... offers a measured assessment of China's global influence, writing concisely about the extent of China's development over recent decades, but also highlighting real challenges and weaknesses." -Tim Summers, International Affairs

Mel Gurtov takes issue with the widespread view that China is on the way to rivaling or even displacing the United States as the dominant world power.

Arguing that China's economic rise has exacerbated problems of social inequality, environmental degradation, official corruption, and more-and that its military capabilities and ambitions are far more limited than many observers have suggested-he makes a strong case that the most productive US policy will be one of engagement on issues of common concern, rather than confrontation or containment.

$2013 / 205$ pages $\cdot$ hc $\$ 49.95 \cdot$ pb $\$ 19.95$

CELEBRATING 31 YEARS OF INDEPENDENT PUBLISHING 180030 TH ST., SUITE 314 • BOULDER, CO 80301 - TEL: 303-444-6684 - www.rienner.com 